\title{
CLÁUSULA GERAL DE PROTEÇÃO SOB A PERSPECTIVA CIVIL- CONSTITUCIONAL: A NORMATIVIDADE DA DIGNIDADE DA PESSOA HUMANA E SUA RELAÇÃO COM OS DIREITOS FUNDAMENTAIS E OS DIREITOS DE PERSONALIDADE
}

\section{CLAUSE GENERAL PROTECTION UNDER CIVIL-CONSTITUTIONAL PERSPECTIVE: THE NORMATIVITY OF HUMAN DIGNITY AND ITS RELATIONSHIP WITH THE FUNDAMENTAL RIGHTS AND PERSONALITY RIGHTS}

\author{
${ }^{1}$ Dirceu Pereira Siqueira \\ ${ }^{2}$ André Vinícius Rosolen
}

\section{RESUMO}

O presente trabalho tem por finalidade, através de análises bibliográficas e estudos de decisões judiciais, fazer uma abordagem teórica e prática sobre a normatividade do princípio da dignidade da pessoa humana como fundamento de interligação das categorias dos direitos fundamentais e dos direitos de personalidade. O princípio da dignidade da pessoa humana é um princípio diretriz de interpretação e aplicação dos direitos subjetivos que viabiliza a concretização da tutela civil-constitucional de proteção ao ser humano nas relações públicas (eficácia vertical) e privadas (eficácia horizontal). A ordem jurídica brasileira consagrou a cláusula geral de proteção da pessoa por meio da incorporação e positivação da dignidade da pessoa humana como princípio e fundamento da República Federativa do Brasil, dos direitos e garantias fundamentais e dos direitos da personalidade, com o objetivo de conferir eficácia - negativa e positiva - aos direitos do ser humano (respeito, proteção e promoção), em face das ofensas e violações perpetradas pelo poder público e pelos particulares e de assegurar a responsabilidade dos ofensores pelos danos causados à vítima. Deste modo, o princípio da dignidade da pessoa humana se consubstancia no princípio jurídico constitucional que concretiza a cláusula geral de proteção da pessoa e fundamenta a interligação jurídica dos direitos fundamentais e dos direitos da personalidade para assegurar a tutela civilconstitucional, por meio de uma relação tríade que forma o núcleo intangível e indissolúvel à unidade normativa.

Palavras-chave: Cláusula geral de proteção da pessoa, Dignidade da pessoa humana, Direitos fundamentais, Direitos de personalidade

\section{ABSTRACT}

This study aims to, through the examination of judicial decisions and bibliographical analysis, take a theoretical and practical approach on the normativity of the principle of human dignity, considering it as the basis for interconnection between the categories of fundamental rights and personality rights. The principle of human dignity guiding principle for the interpretation and application of legal standards as civil-constitutional safeguards to

\footnotetext{
${ }^{1}$ Doutor em Sistema Constitucional de Garantia de Direitos pelo Instituição Toledo de Ensino, Paraná, (Brasil) Email: tutortreinamneto@gmail.com

${ }^{2}$ Mestrando em Ciências Jurídicas Centro de Ensino Superior de Maringá - CESUMAR, Paraná, (Brasil).
} 
protect the rights of people in public (vertical effectiveness) and private relations (horizontal effectiveness). The Brazilian law established the general principle of the protection of the person through the embodiment and positivation of the dignity of the human person as a principle and foundation ofthe Federative Republic of Brazil,the personality rights and the fundamental guarantees and rights, in order to grant positive and negative effectiveness to the rights of man (respect, protection and promotion), considering the violations and offenses perpetrated by public authorities and private individuals and to ensure the accountability of offenders for the damages they caused. Thus, the principle of human dignity is embodied in the constitutional legal principle which fulfills the general clause of protection of the person and establishes the interconnection of legal the fundamental rights and the personality rights to ensure the civil-constitutional protection through a triad relationship that unites the intangible and indissoluble core with the normative unit.

Keywords: General clause of protection of the person, Principle of human dignity, Fundamental rights, Personality rights

\section{INTRODUÇÃO}

O princípio da dignidade da pessoa humana se constitui em uma cláusula geral de proteção da pessoa que fundamenta a interligação dos direitos fundamentais e dos direitos da personalidade na ordem jurídica brasileira, tendo por objetivo assegurar o respeito, proteção e promoção dos direitos do indivíduo em todas suas concepções, como integridade física, moral e intelectual, bem como ao desenvolvimento de sua personalidade.

A importância do trabalho se justifica em razão dos reflexos pelo uso da normatividade da dignidade humana para interligar as diferentes categorias jurídicas - direitos fundamentais e direitos da personalidade - na construção de uma cláusula geral da pessoa na perspectiva da constitucionalização do direito civil. Nesse sentido, o princípio da dignidade da pessoa humana se projeta como gênero (fim), enquanto que os direitos fundamentais e os direitos da personalidade são espécies normativas (meios) que permitem a efetivação da tutela civil-constitucional e a concretização da cláusula geral da pessoa.

A cláusula geral de proteção do indivíduo surge com a incorporação da dignidade da pessoa humana e com o fenômeno da constitucionalização do direito civil, que (re)personalizou o Direito para centralizar a pessoa como o fim do Estado e da sociedade, superando a tradicional dicotomia entre os regimes de direito público-privado. Por tais razões, através da constitucionalização houve a repersonalização do Direito e o princípio da dignidade da pessoa humana passou a fundamentar a criação normativa dos direitos fundamentais e dos direitos de personalidade. 
Não obstante, a cláusula geral de proteção tem a finalidade de assegurar o respeito e a proteção das qualidades intrínsecas das pessoas em todas as suas dimensões físicas, morais e intelectuais, bem como visa censurar as violações perpetradas pelos particulares e pelo poder público. O surgimento da cláusula geral de proteção ocorreu depois dos acontecimentos das guerras mundiais e se sedimentou em razão da globalização e dos avanços tecnológicos como forma de proteção à pessoa.

Os direitos fundamentais são direitos subjetivos do ser humano incorporados pela Constituição, que objetivam resguardar a proteção dos direitos e garantias individuais das violações praticadas pelo poder público. Já os direitos de personalidade são direitos subjetivos que visa à proteção dos atributos intrínsecos da pessoa em seus aspectos físicos, morais e intelectuais, em face das ofensas praticadas pelos particulares nas relações privadas.

A diferença dos regimes jurídicos foram remodelados pelo princípio da dignidade da pessoa humana, através do fenômeno da constitucionalização do direito civil, que realizou a unificação e a integração das categorias dos direitos fundamentais e dos direitos de personalidade para conferir maior eficácia na proteção dos direitos da pessoa e concretizar o novo sentido da tutela civil-constitucional, no plano infraconstitucional e no plano constitucional.

O princípio da dignidade da pessoa humana está conexo com os direitos fundamentais e os direitos de personalidade em uma relação tríade, que viabiliza a construção e a formação da cláusula geral de proteção da pessoa e assegura a reparação pelos danos causados à vítima em razão dos atos ofensivos e violações praticadas pelo Estado e pelos particulares nas relações público-privadas.

Portanto, a dignidade da pessoa humana representa o fundamento da conjugação das categorias dos direitos fundamentais e de personalidade para proteger os valores intrínsecos da pessoa e os direitos subjetivos do indivíduo, por meio da unidade normativa da cláusula geral de proteção.

\section{DIGNIDADE DA PESSOA HUMANA COMO CLÁUSULA GERAL DE PROTEÇÃO}

A dignidade da pessoa humana é um princípio jurídico previsto na Constituição Federal, utilizado para salvaguardar o mínimo de respeito (tratamento), proteção (defesa) e promoção de direitos das pessoas (concretizações) em razão da própria condição humana da pessoa, com extensão nas relações públicas e nas relações particulares. Por seu turno, a 
dignidade da pessoa humana se caracteriza pela cláusula geral de proteção da pessoa que fundamenta a existência dos direitos fundamentais e dos direitos de personalidade.

O termo dignidade deriva do latim "dignitas", que designa virtude, honra ou consideração da qualidade moral que possuía determinada pessoa, bem como a função para justificar o próprio respeito do indivíduo. Do mesmo modo, poderá ser compreendida como a distinção ou honraria conferida à pessoa (SILVA, 2014, p. 467).

No pensamento da antiguidade clássica, a dimensão política da dignidade se refere à posição social ocupada pelo indivíduo na sociedade. A dimensão filosófica da dignidade designava a qualidade inerente do ser humano dotado de liberdade e igualdade que os diferenciavam dos demais seres (SARLET, 2015a, p. 33). O sentido atribuído à dignidade estava associado com um dever de respeito, honra e deferência a determinados indivíduos e instituições merecedores de tratamento distintos, isto é, estava relacionado ao status pessoal e alguns indivíduos pelas posições políticas ou sociais que ocupavam, fazendo referência à proeminência de determinadas instituições ou supremacia dos poderes (BARROSO, 2014, p. $13)$.

No periodo medieval, a noção de digndade sofreu modificações por influências do Cristianismo. Os seres humanos possuem dignidade porque são obras da divindade e possuem uma relação de aproximação com o divino, sendo que o homem foi feito à imagem e semelhança de Deus - "Imago Dei" -, revigorando os valores da fraternidade e de solidariedade de cada pessoa em amar o seu próximo na mesma proporção.

A Modernidade foi marcada pelo Renascimento (antropocentirsmo) que provocou modificações de pensamentos e estruturas sociais - o homem passou a ser o centro do universo - sendo que a dignidade da pessoa passou a representar o sentido de liberdade e o livro arbítrio do invidíduo (SARLET, 2015a, p.35-36).

No entanto, foi no pensamento de Imannuel Kant que a dignidade da pessoa humana desvinculou das demais acepções clássicas, passando a ser fundamentada na autonomia da vontade da pessoa, em que o homem é o fim em si mesmo, não um meio. ${ }^{1}$ Neste sentido, Kant define a dignidade como um status moral que confere ao indivíduo a aptidão de possuir direitos e deveres, com oponibilidade "erga omnes", de respeitar às pessoas da coletividade e de abster-se de realizar agressões à autonomia do sujeito (COSTA NETO, 2014, p. 25). 
No século XVIII, remanesce a consagração da dignidade da pessoa como pressuposto de que o homem, na condição de sua própria natureza e independente de qualquer circunstância, é titular de direitos que deve ser reconhecido e respeitado por outros seres semelhantes e pelo Estado (SARLET, 2015a, p. 47). A ideia de dignidade se constitui a partir da natureza humana racional e da liberdade da pessoa de fazer escolhas morais e de determinar o seu próprio destino, o que justificou sua consagração em documentos internacionais e nas Constituições do Estado.

A dignidade da pesoa humana teve juridicidade por meio dos intereses do sistema sociopolíticos como forma de reação a práticas do nazismo e facismo na Segunda Guerra Mundial, bem como contra todas as formas de degradação do ser humano (ROCHA, 1999, p.

25). Diante dos acontecimentos, a dignidade da pessoa humana foi incorporada no discurso político como forma de promover a paz mundial, a democracia e a proteção aos direitos humanos, sendo, posteriormente, consagrada em diversos tratados internacionais de Direitos Humanos e nas Constituições do Estado, tendo em vista o holocausto provocado pelos nazistas na Segunda Guerra Mundial, que fez reaproximar o direito da moral e da filosofia política com a tarefa de modificar o sistema de interpretação das normas jurídicas conforme a ética e a dignidade da pessoa humana (BARROSO, 2014, p.18-19).

No século XX, marcado pelas barbáries e crueldades das grandes guerras mundiais, a dignidade humana foi incorporada como norma jurídica para resguardar o mínimo de proteção e respeito aos seres humanos. Neste sentido, o preâmbulo da Carta das Nações Unidas de

1945 prevê a reafirmação dos direitos fundamentais do homem, da dignidade e no valor do ser humano, como forma de preservação das futuras gerações marcada pelo flagelo da guerra, que por sua vez trouxe sofrimentos indivíveis à toda sociedade mundial.

Deste modo, a dignidade humana se tornou o valor fundante do sistema dos direitos fundamentais e se converteu no patrimônio jurídico-moral da pessoa humana estampada nos direitos subjetivos incorporados e assegurados pelo sistema constitucional (ROCHA, 1999, p.

32). Segundo Luis Roberto Barroso, a compreensão contemporânea sobre dignidade da pessoa humana se assenta no pressuposto de que cada ser humano possui um valor instrínseco e desfruta uma posição especial no universo (BARROSO, 2014, p. 14). 
A dignidade humana é um princípio fundamental que forma o núcleo de harmonização das normas jurídicas, com a função de dirigir os meios de interpretação à concordância normativa para aplicar o valor de um princípio ou de preservar o conteúdo axiológico da norma jurídica. O princípio da dignidade possui conceito aberto que serve como instrumento de estabilidade constitucional, adaptando o seu conteúdo à evolução da sociedade, sem, contudo, alterar o texto da lei. ${ }^{2}$

Ingo Wolfgang Sarlet define a dignidade da pessoa humana de forma aberta $\mathrm{e}$

inclusiva sobre a própria condição humana nas relações intersubjetivas:

\begin{abstract}
"Assim sendo, termos por dignidade da pessoa humana a qualidade intrínseca e distintiva reconhecida emcada ser humano que o faz merecedor do mesmo respeito e consideração por parte do Estado e da comunidade, implicando, neste sentido, um complexo de direitos e deveres fundamentais que as segurem a pessoa tanto contra todo e qualquer ato de cunho degradante e desumano, como venham a the garantir as condições existenciais mínimas para uma vida saudável, além de propiciar e promover sua participação ativa e coresponsável nos destinos da própria existência e da vida em comunhão com os demais seres humanos, mediante o devido respeito aos demais seres que integrama rede da vida." (SARLET, 2015a, p. 70-71).
\end{abstract}

Do mesmo modo, Jesús González Pérez entende que a dignidade da pessoa humana está associada com a noção de valor superior e princípio fundamental consagrado na Constituição que obriga os poderes públicos e os particulares. Por seu turno, define a dignidade humana como a categoria que corresponde ao homem, como ser humano dotado de inteligência e de liberdade, distinto e superior a toda a criação, que implica no tratamento

condizente com a natureza humana. Outrossim, a violação da dignidade humana ocorrerá sempre que desrespeitar essa essencial superioridade do homem ou de ser considerado como qualquer outra parte da natureza, sendo indigno tudo o que se presume de degradação do posto central que corresponde à criação (PÉREZ, 2011, p. 165).

Os sistemas que adotam a dignidadade humana como fundamento axiológico do ordenamento jurídico prima por realçar a diferença do ser humano dos demais seres (COSTA NETO, 2014, p. 35). A dignidade humana é uma norma jurídica com qualificação de conteúdo ético e moral - valores instrínecos do ser humano - que infunde respeito e proteção à pessoa, em virtude de desfrutar de uma posição especial e distinta no universo (SARLET, 
2015a, p. 82-

83).

A dignidade da pessoa humana possui duas dimensões, normativa (princípio jurídico) e outra axiológica (valores do ser humano), que se relacionam e se complementam mutuamente. Nesse contexto, a dignidade apresenta uma dimensão interna que expressa o valor intrínseco ou próprio de cada indivíduio que é inviolável, e outra dimensão externa, que representa os direitos, aspirações e responsabilidades de proteger a pessoa das ofensas e violações (BARROSO, 2014, p. 62).

Nessa linha de pensamento, a dignidade da pessoa humana é um princípio jurídico constitucional - norma jurídica - que enuncia direitos e reconhece os meios de responsabilidade de respeito e proteção aos valores intrínsecos do ser humano, ou seja, o sentido normativo implica no tratamento condizente da pessoa em razão da própria condição de ser humano e de assegurar uma mínima respeitabilidade do indivíduo.

A Declaração Universal dos Direitos Humanos consagrou a dignidade da pessoa humana para enunciar os direitos humanos fundamentais de forma inalienável e em igualdade de condições, bem como para reconhecer os valores intrínsecos e inerentes à pessoa humana, com fundamento da liberdade, justiça e paz social.

$\mathrm{O}$ art. $1^{\circ}$, inciso III, da Constituição de 1988 prevê a dignidade humana como fundamento da República Federativa do Brasil e do Estado Democrático de Direito. Com efeito, a dignidade é uma norma constitucional que reconhece os direitos das pessoas e a inviolabilidade dos valores humanos, conferindo unidade de interpreção, sentido à aplicação das normas jurídicas e legitimidade para a ordem constitucional.

$\mathrm{O}$ texto constitucional assegura o respeito e a proteção dos direitos das pessoas elencados em seu texto com fundamento no princípio da dignidade humana (direitos e garantias individuais dos cidadãos), a fim de possibilitar o desenvolvimento da personalidade do indivíduo sem qualquer forma de discriminação e sem interferência dos poderes constiuídos e dos particulares, concretizando os objetivos fundamentais para construção de uma sociedade livre, justa e solidária.

A dignidade humana se assenta no fundamento de todo o sistema jurídico positivo, transformando no núcleo essencial e indivisívelde fundamentação dos direitos das pessoas consagrados pela norma constitucional e infraconstitucional. O Estado e os particulares possuem o dever jurídico - responsabilidade - de respeitar e proteger a dignidade humana de qualquer indivíduo contra os abusos e violações. 
Neste passo, a dignidade humana constitui não só na dimensão garantia negativa de respeito e proteção de que a pessoa não será objeto de ofensas e humilhações, mas também implica na dimensão positiva de assegurar o desenvolvimento da personalidade de cada indivíduo, mediante o reconhecimento da autodisposição de cada pessoa para dispor sem interferências ou impedimentos e de autodeterminação para projetar-se conforme a razão humana (LUÑO, 2010, p. 324).

A partir da dignidade se irradia os valores éticos e morais das pessoas para toda ordem jurídica, uma vez que é pressuposto para existência de direitos, isto é, a dignidade da pessoa humana reconhece os direitos subjetivos do indivíduo como necessários e indispensáveis para o desenvolvimento integral da personalidade.

Por seu turno, a eficácia do princípio da dignidade humana se subdivide em eficácia positiva e negativa. A eficácia positiva (prestacional) significa que o princípio da dignidade humana vincula a atuação do poder público e do terceiro, mediante a imposição de comportamento positivo (obrigações de fazer e de dar) para promover os direitos das pessoas e de assegurar mínimas condições para o seu exercício. Na eficácia negativa (limitação) o princípio da dignidade estabelece abstenções ou limites para atividades dos poderes públicos e dos particulares, com a finalidade de assegurar o respeito e a proteção dos direitos das

pessoas.

No entanto, vale ressaltar que a preocupação dos juristas reside na aplicação do princípio da dignidade da pessoa humana no plano real ou concreto, não ficando apenas no ponto de vista formal e abstrato. O Estado e os próprios indivíduos, nas suas projeções sociais, devem efetivar o mandamento constitucional da dignidade humana para produzir os efeitos concretos projetados pela norma.

De outro modo, a dignidade da pessoa humana exerce uma função de integração e interpretativa/hermenêutica ${ }^{3}$ que possibilita o diálogo e a interligação com as categorias dos direitos da personalidade e dos direitos fundamentais. O conteúdo da dignidade humana é o mecanismo jurídico utilizado para conferir uma relação dialógica com os direitos fundamentais e os direitos da personalidade, para abranger a proteção da pessoa nas suas respectivas relações públicas e privadas.

Ingo Wolfgang Sarlet reconhece a indissociável vinculação entre dignidade da pessoa humana com os direitos humanos e fundamentais como postulado que se assenta o Direito Constitucional contemporâneo (SARLET, 2015a, p. 28). Do mesmo modo, Luís 
Roberto Barroso assevera que a dignidade da pessoa humana e os direitos humanos e fundamentais estão intimamente relacionados, uma vez que expressa os valores morais que singularizam as pessoas merecedoras de igual respeito e consideração, bem como porque contempla os direitos fundamentais como positivação da moral por meio de normas jurídicas (BARROSO, 2014, p. 75).

A pessoa possui valores que lhes são intrísecos pela condição humana, capazes de promover seu devenvolvimento na sociedade. A dignidade integra os valores do ser humano, que conduz e centraliza a personalidade de cada indivíduo, ou seja, se apresenta como fonte de aspirações, desejos e formas de manifestações individuais, bem como o meio de preservar a individualidade da pessoa (ARAÚJO, 2008, p. 226).

Para José Afonso da Silva (1998, p. 94), a dignidade da pessoa humana é um princípio fundamental que inspiram a ordem jurídica, uma vez que possui natureza de valor supremo que dimensiona e humaniza a pessoa para realização e a efetivação dos direitos fundamentais.

Não obstante, a dignidade da pessa humana coexite com os direitos fundamentais e os direitos de personalidade como uma unidade indivisível que se complementa para atender as seguintes finalidades jurídicas: a) assegurar o respeito de tratamento ao ser humano sem discriminação e desprezo de não considerar a pessoa como um objeto/intrumento; b) assegurar a proteção dos direitos e as qualidades da pessoa em face dos abusos e arbitrariedades praticadas pelo Estado e pelos particulares; c) promover os direitos subjetivos das pessoas ou de assegurar as mínimas condições para o seu exercício e para o desenvolvimento de sua personalidade.

Em suma, a dignidade da pessoa humana se apresenta como cláusula geral de proteção da pessoa, através da incorporação e anunciação dos direitos fundamentais e dos direitos da personalidade na ordem jurídica, em face dos abusos e violações praticadas nas relações jurídicas com o poder público (eficácia vertical) e com os particulares na órbita privada (eficácia horizontal).

\subsection{A DISTINÇÃO NORMATIVA DAS CATEGORIAS DOS DIREITOS FUNDAMENTAIS E DOS DIREITOS DE PERSONALIDADE E A CONSTITUCIONALIZAÇÃO DO DIREITO CIVIL}

Os direitos humanos, os direitos fundamentais e os direitos de personalidade são direitos essenciais do ser humano que foram reconhecidos e positivados na ordem jurídica nacional e internacional para assegurar a proteção à pessoa das ameaças, abusos e violações 
perpetradas pelo Estado ou pelos particulares. A distinção das categorias dos direitos fundamentais e dos direitos de personalidade reside no fato de que os direitos fundamentais pertencem ao regime de direito público (Direito Constitucional) e os direitos de personalidade ao regime de direito privado (Direito Civil), sendo que os direitos fundamentais incidem na relação vertical entre indivíduo e Estado, enquanto que os direitos de personalidade são aplicados na relação horizontal entre os particulares.

Neste sentido, Rabindranath Valentino Aleixo Capelo de Souza entende que a relação entre os direitos fundamentais e os direitos da personalidade emerge a partir da sobreposição ao nível da pessoa humana de dois planos jurídicos: do direito civil (direitos da personalidade) e do direito constitucional (direitos fundamentais). Porém, ressalta que, embora haja diversos direitos de personalidade constitucionalmente reconhecidos como direitos fundamentais, nem todos os direitos de personalidade constituem direitos fundamentais, por outro lado, nem todos direitos fundamentais são direitos de personalidade, pois se revestem de sentido, função e aplicações distintas (SOUZA, 2011, p.584).

Do mesmo modo, Jorge Miranda entende que os direitos fundamentais e os direitos de personalidade possuem significados distintos, uma vez que os direitos fundamentais pertencem ao Direito Constitucional e pressupõe uma relação de poder, com incidência nas relações públicas e privadas. Os direitos de personalidade são aplicados ao Direito Civil em uma relação de igualdade entre os indivíduos na esfera privada (MIRANDA, 2012, p.76).

Por sua vez, Carlos Alberto Bittar (2015, p. 56) e Elimar Szaniawski (2005, p. 45) reproduzem o entendimento dos civilistas brasileiros sobre a distinção das categorias, dizendo que os direitos fundamentais são os direitos do ser humano que objetivam a proteção do indivíduo contra a ingerência e os abusos do Estado, ou seja, são direitos que pertencem ao direito público que decorrem de uma relação vertical entre indivíduo e Estado, com o intuito de limitar ao exercício do poder. Em contrapartida, os direitos de personalidade são direitos do ser humano aplicados na esfera do direito civil, que visa a proteção da pessoa contra as ameaças e violações perpetrada nas relações horizontais entre os particulares.

A diferenciação formal das categorias dos direitos fundamentais e dos direitos de personalidade ocorre por meio da aplicação normativa, competência legislativa, regime jurídico e sistema de garantia de direitos. ${ }^{4}$ No entanto, no seu aspecto material não existe nenhuma diferenciação, tendo em vista que formam um núcleo intangível e uma unidade indivisível para salvaguardar o respeito e a proteção da dignidade da pessoa humana. 
Os direitos fundamentais e os direitos de personalidade possuem as mesmas características no seu conteúdo e finalidade, visto que objetivam a concretização da tutela civil-constitucional de proteção da pessoa e dos valores intrínsecos dos indivíduos com fundamento no princípio da dignidade da pessoa humana. Deste modo, o princípio da dignidade da pessoa humana se constitui na cláusula geral de proteção da pessoa porque realiza a interligação das categorias dos direitos fundamentais e dos direitos de personalidade como um núcleo/unidade normativa que assegura a proteção e os direitos do ser humano, superando a tradicional dicotomia entre o direito público e o direito privado para formação da tutela civil-constitucional.

A constitucionalização do direito está associada ao efeito expansivo das normas constitucionais por todo o ordenamento jurídico, sendo que os valores e as normas jurídicas contempladas pela Constituição condicionam a validade e o sentido de todo o Direito, nas suas relações públicas e privadas (BARROSO, 2015, p. 16-17). A readequação do direito se deu após as atrocidades ocorridas no período da Alemanha Nacional Socialista (Nazismo), tornando indispensável a normatização da dignidade da pessoa humana para reaproximar o direito da moral e conferir maior proteção às pessoas.

O fenômeno da constitucionalização foi um novo processo hermenêutico de compatibilização do Código Civil e da legislação extravagante do direito privado, com os dispositivos da Constituição Federal, sendo reivindicado do jurista um novo sentido de interpretação do Código Civil à luz da Constituição Federal. As disposições legais previstas no Código Civil e no regime privado foram editadas e contempladas pela norma constitucional para formular a unificação de direitos pessoais e unidade do núcleo normativo (TEPEDINO, 2004a, p. 1).

A Constituição consagrou dignidade da pessoa humana para limitar a atuação do Estado e para promover a repersonalização do Direito Civil com ênfase nos valores existenciais e no espírito da pessoa, mediante o reconhecimento dos direitos da personalidade, nas suas dimensões físicas, morais e intelectuais (BARROSO, 2015, p. 33).

Por tais razões, o princípio da dignidade da pessoa humana é o fundamento jurídicopositivo que permite a conexão dos direitos fundamentais e os direitos da personalidade para

formar a unidade normativa de cláusula geral de proteção à pessoa e para salvaguardar a tutela civil-constitucional contra as ofensas empregadas pelo Estado e pelos particulares. 


\subsection{DIREITOS FUNDAMENTAIS SOB UMA PERSPECTIVA CONCRETIZADORA}

Os direitos fundamentais e os direitos humanos são diferenciados quanto ao plano de aplicação e incorporação na ordem jurídica. Os direitos fundamentais são direitos incorporados na Constituição do Estado e os direitos humanos estão previstos em normas internacionais, isto é, os direitos humanos são direitos naturais e universais frutos da construção histórica e sedimentados ao longo do tempo, sendo, posteriormente, incorporados nas Constituições como direitos fundamentais.

Conforme ensina Ingo Wolfgang Sarlet, os direitos do homem são direitos naturais que não foram positivados, os direitos humanos são direitos do indivíduo positivado na esfera internacional e os direitos fundamentais são os direitos do ser humano reconhecidos, outorgados e protegidos pela norma constitucional interna de cada Estado (SARLET, 2015b, p. 30).

Cabe ressaltar que os direitos fundamentais surgiram através das lutas e conquistas sociais interligadas com o processo de positivação - constitucionalização - dos direitos humanos, como forma de resistência à opressão das autoridades estatais e com a função limitação ao exercício do poder do Estado. A construção dos direitos fundamentais se iniciou com os movimentos políticos e sociais para assegurar as liberdades individuais.

No século XVIII, a Declaração de Direitos de Virgínia (1976) e a Declaração dos Direitos do Homem e do Cidadão (1789), incorporaram os direitos do ser humano como forma de defesa da pessoa contra o Estado. ${ }^{5}$ Com efeito, foi a partir das revoluções inglesa e francesa que surgiu os direitos fundamentais como forma de limitação do poder e defesa dos direitos do homem (MIRANDA, 2012, p. 26).

Ocorre que, somente no século XIX, com o advento da promulgação da Constituição Alemã, é que foi reconhecida a categoria dos direitos fundamentais. Segundo Konrad Hesse, os direitos fundamentais tiveram sua origem triunfal com a elaboração das magnas Declarações de Direitos Americana e Francesa ao final do século XVIII, porém foi expressamente denominada pelas Constituições dos Estados alemães no século XIX (HESSE,

2009, p. 26).

De acordo com Luiz Alberto David Araújo e Vidal Serrano Nunes Júnior, os direitos fundamentais são vocacionados à proteção da dignidade da pessoa humana, constituindo uma 
natureza poliédrica de diversas dimensões que visa resguardar a liberdade do ser humano (direitos e garantias individuais), de atender suas necessidades materiais (direitos econômicos, sociais e culturais) e de preservação da pessoa (direito à fraternidade e solidariedade) como forma de antepor as agressões à dignidade (ARAÚJO; NUNES JÚNIOR, 2007, p. 111).

Dimitri Dimoulis e Leonardo Martins definem os direitos fundamentais como direitos públicos-subjetivos das pessoas consagrados na norma constitucional que tem por finalidade limitar o exercício do poder estatal em face da liberdade individual (DIMOULIS; MARTINS, 2014, p. 41). Do mesmo modo, Ingo Wolfgang Sarlet expressa que os direitos fundamentais são os direitos dos seres humanos reconhecidos e positivados na ordem constitucional de determinado Estado (SARLET, 2015b, p. 29).

Antonio Enrique Pérez Luño entende que os direitos fundamentais são as faculdades e instituições - direitos intrínsecos da pessoa humana - consagrados na Constituição, que objetiva proteger os indivíduos contra as violações do Estado e dos particulares e de promover a dignidade da pessoa humana, para construção de uma sociedade livre, justa, igualitária e solidária, sem preconceitos e quaisquer outras formas de discriminação (LUÑO, 2010, p. 50).

A incorporação dos direitos fundamentais ocorreu em momentos históricos distintos, conforme as exigências, necessidades e o aumento das demandas sociais voltadas para proteção dos direitos individuais. As dimensões dos direitos fundamentais estão subdividas em direitos de primeira dimensão (direitos de liberdade), direitos de segunda dimensão (direitos econômicos, sociais e culturais), direitos de terceira dimensão (direitos difusos e coletivos) e direitos de quarta dimensão.

Os direitos de primeira dimensão são os direitos civis e políticos destinados a assegurar o respeito e a proteção das liberdades públicas individuais das pessoas, mediante a limitação do poder estatal. Já os direitos de segunda dimensão são os direitos econômicos, sociais e culturais que visam reduzir as desigualdades de acordo com aplicação do princípio da igualdade material, que exigem uma prestação positiva por parte do Estado para atender as mínimas condições e necessidades humanas, sob a ótica da igualdade material e da realização da justiça social.

Os direitos de terceira dimensão são os direitos difusos e coletivos destinados à proteção de grupos de indivíduos e a coletividade em razão do desenvolvimento social, da tecnologia e da ciência. Os direitos de quarta dimensão são os direitos relativos à manipulação do patrimônio genético e ao desenvolvimento tecnológico (clonagem, alimentos transgênicos, 
fertilização “in vitro”). Conforme Paulo Bonavides, a globalização da política e a institucionalização do Estado Social implicou na elaboração da quarta dimensão para abranger

a universalidade das relações humanas e a proteção do direito à democracia, direito à informação e direito ao pluralismo (BONAVIDES, 2014, p. 585).

A dimensão subjetiva dos direitos fundamentais consiste no comportamento ou vontade de produzir efeitos sobre as relações jurídicas, por meio de uma exigência de ação negativa (respeito e proteção), positiva (promoção) ou de competência (modificação de posições jurídicas). Por sua vez, a dimensão objetiva significa que os direitos fundamentais é um princípio de ordem constitucional, que exerce a função de limitar o poder e diretriz para atuação dos poderes constituídos (MENDES; BRANCO, 2014, p. 167).

Por outro lado, os direitos fundamentais são classificados em três categorias distintas, que compreende os direitos de defesa (dever de abstenção ou prestações negativas), direito de prestação (dever de promoção ou prestações positivas) e direitos de participação (prestações positivas e negativas).

No direito de defesa, os direitos fundamentais protegem os indivíduos do Estado e dos particulares, mediante a imposição de deveres de caráter negativo para preservar as liberdades públicas e a autodeterminação do indivíduo contra os abusos e violações. No direito de prestação, o Estado tem o dever de agir para realização dos direitos fundamentais, mediante o fornecimento de prestações materiais - bens e de serviços públicos - para atender determinados direitos ou por meio de prestação jurídica para regular determinada situação para defesa de direitos.

Por conseguinte, os direitos de participação obriga o Estado de fornecer meios adequados e necessários para assegurar o exercício da cidadania com a participação dos indivíduos nos assuntos e interesses estatais (perspectiva positiva), bem como de proibir a criação de mecanismos que inviabilizem a sua participação (perspectiva negativa).

Do mesmo modo, os direitos fundamentais possuem certas características que são distintas em relação aos demais direitos. As principais características dos direitos fundamentais são as seguintes: fundamentalidade, historicidade; universalidade; irrenunciabilidade e inalienabilidade; imprescritibilidade e indivisibilidade.

Os direitos e garantias fundamentais estão previstos na Constituição Federal, sendo subdivididos nas seguintes espécies: direitos e deveres individuais e coletivos (art. $5^{\circ} \mathrm{CF} / 88$ ), direitos sociais (art. $6^{\circ}$ ao art. $11 \mathrm{CF} / 88$ ), direitos de nacionalidade (art. 12 ao art. $13 \mathrm{CF} / 88$ ), 
e direitos políticos (art. $17 \mathrm{CF} / 88$ ). A constituição assegura dos direitos fundamentais individuais como direito à vida, à liberdade e à igualdade (art. $5^{\circ} \mathrm{CF} / 88$ ), o direito à integridade física (art. 5 $5^{\circ}$ inciso III, CF/88), os direitos à intimidade, vida privada, honra $\mathrm{e}$

imagem das pessoas (art. $5^{\circ}$, inciso $\mathrm{X}, \mathrm{CF} / 88$ ) e os direitos autorais (art. $5^{\circ}$, incisos IX $\mathrm{e}$

XXVII, CF/88), entre outros.

As violações aos direitos fundamentais podem ocorrer a partir de uma relação vertical de esfera pública (relação indivíduo versus Estado) ou de uma relação horizontal entre os particulares (relação indivíduo versus indivíduo). A eficácia vertical representa a aplicação das normas de direitos fundamentais nas relações entre o cidadão e o Estado para resguardar a proteção dos direitos individuais das violações perpetradas pelos agentes estatais. Por sua vez, a eficácia horizontal consiste na aplicação das normas dos direitos fundamentais nas relações particulares, que objetiva a proteção dos direito do ser humano em face dos atos de violação praticados por particulares.

Portanto, os direitos fundamentais são direitos subjetivos do ser humano previstos pela norma constitucional e regidos pelo direito público, que visa limitar o exercício do poder e assegurar o respeito e a proteção da pessoa das ofensas e violações praticadas pelos agentes do Estado e pelos particulares nas relações privadas e intersubjetivas.

\subsection{DIREITOS DA PERSONALIDADE SOB UMA PERSPECTIVA HORIZONTALIZADA}

A compreensão dos direitos da personalidade demanda uma prévia análise sobre o que significa pessoa, personalidade e personalidade jurídica. A pessoa é o ser humano dotado de individualidade e racionalidade em ralação aos demais seres. A personalidade representa as características e as qualidades intrínsecas da pessoa. Por sua vez, a personalidade jurídica consiste na aptidão e suscetibilidade da pessoa titularizar direitos e contrair obrigações nas relações sociais, tendo por objeto a proteção de bens jurídicos da pessoa humana (físicos, psíquicos, morais e intelectuais do ser humano).

A categoria dos direitos da personalidade surgiu no Direito Alemão, com o advento da Lei Fundamental de Bonn e da construção jurisprudencial, para atender a proteção dos atributos das pessoas em face dos abusos e violações praticadas nas relações privadas. Os direitos da personalidade, inicialmente, sugiram como direitos fundamentais (direito da 
personalidade público), posteriormente, forma aplicados nas relações particulares com o objetivo de proteger os atributos da personalidade e as qualidades intrínsecas do ser humano.

No século XIX, os direitos subjetivos foram fracionados em direitos público de personalidade e direito privado de personalidade. Os direitos públicos de personalidade são os direitos fundamentais, previstos nas Constituições e na Declaração Universal dos Direitos do Homem e do Cidadão, destinados à defesa das pessoas contra os abusos e violações

perpetradas pelo Estado. Os direitos privados de personalidade que são os direitos da pessoa aplicados e regulados nas relações entre os particulares (SZANIAWSKI, 2005, p. 43-44).

Os direitos de personalidade foram aplicados como direitos fundamentais, sendo que primeiro foram consagrados pelo direito público em que o Estado deveria abster e promover os direitos das pessoas, em seguida, foram incorporados pelos Códigos para disciplinar os atributos e as qualidades essenciais das pessoas nas relações privadas com outros indivíduos.

No século XXI, as Constituições dos Estados e os Códigos passaram a disciplinar a cláusula geral dos direitos da personalidade à luz do princípio da dignidade da pessoa humana, o que justificou a formulação e a introdução da categoria dos direitos de personalidade na ordem jurídica, como direito sobre a própria pessoa, existência pessoal ou direito à exteriorização e desenvolvimento das faculdades de pensar e sentir (GONÇALVES, 2008, p. 78).

Nesse sentido, com a promulgação da Constituição da República Federal da Alemanha de 1949 passou admitir a existência de um direito geral de personalidade como direito subjetivo, com fundamento na dignidade da pessoa humana e no desenvolvimento da personalidade (SOUZA, 2011, p. 85). A construção da cláusula geral de proteção dos direitos da personalidade foi desenvolvida com a Constituição da República Federal da Alemanha (Lei Fundamental de Bonn), no seu art. $1^{\circ}$, n1 (dignidade da pessoa humana) e no art. $2^{\circ}$, n1 (desenvolvimento da personalidade). ${ }^{6}$

Segundo Orlando Gomes os direitos da personalidade são o conjunto de direitos considerados essenciais à pessoa humana com a finalidade de resguardar a sua dignidade e a necessidade de proteção contra práticas abusivas e atentatórias à personalidade do indivíduo (GOMES, 1996, p. 149). Do mesmo modo, Francisco Amaral entende que os direitos da personalidade são direitos subjetivos que visam à proteção dos bens e valores do ser humano de natureza física, moral e intelectual. ${ }^{7}$ 
Em síntese, os direitos da personalidade são direitos subjetivos das pessoas faculdades e prerrogativa - que visam assegurar o respeito e a proteção dos bens e dos atributos da pessoa nas suas relações privadas. $O$ direito positivo confere proteção aos atributos e qualidades da pessoa humana (integridade física, moral e intelectual), facultando ao titular a reparação civil dos danos por meio do ajuizamento de ações judiciais preventivas e reparadoras.

A legislação brasileira confere proteção jurídica às pessoas contra qualquer tipo de ameaça ou ofensas/violações à integridade física, moral ou intelectual, sendo assegurado ao titular - vítima da ofensa - o direito de requer a cessação da ameaça ou a reparação dos danos pelas lesões. A norma jurídica assegura à pessoa - ente autônomo e individualizado - a faculdade de proteger os atributos e as características da personalidade humana nas relações privadas.

$\mathrm{Na}$ ordem jurídica brasileira os direitos da personalidade estão localizados no texto constitucional e no Código Civil. A Constituição prevê o direito à vida e o direito à liberdade (art. 5', "caput", CF/88) bem como o direito à intimidade, direito à vida privada, direito à honra, direito à imagem (art. 5 , inciso X, CF/88). Por outro lado, o Código Civil disciplina a tutela geral de personalidade (art. $12 \mathrm{CC}$ ), direito de disposição do próprio corpo e à integridade física (art. $13 \mathrm{CC}$ ), direito à incolumidade psicofísica (art. $14 \mathrm{CC}$ ), direito ao nome (art. $16 \mathrm{CC}$ ) e direito à vida privada (art. $21 \mathrm{CC}$ ).

$\mathrm{O}$ objeto dos direitos de personalidade consiste na proteção dos valores e atributos do ser humano que compreende o aspecto físico, moral e intelectual (vida humana, corpo, integridade física e psíquica, honra, imagem, liberdade, nome, intimidade), com fundamento na dignidade da pessoa humana (AMARAL, 2014, p. 304-305). Os direitos de personalidade são classificados em três dimensões distintas: integridade física (tutela do corpo humano); integridade moral (valores do ser humano); e integridade intelectual (inteligência humana), que estão fundamentadas nos elementos que compõe a pessoa humana (corpo, alma e intelecto).

Nesse sentido, de acordo com a tradicional civilística, os direitos da personalidade estão subdivididos nos seguintes aspectos: a) integridade física que compreende a proteção jurídica do direito à vida, direito ao corpo (corpo vivo), direito ao cadáver (corpo morto); b) integridade moral que confere proteção ao direito à privacidade (segredo e intimidade), direito à liberdade (civil, política e religiosa), direito à vida privada, direito à imagem (retrato, atributo e voz), direito à honra (objetiva e subjetiva), direito ao nome (prenome, 
sobrenome, pseudônimo) e direito à identidade pessoal; c) integridade intelectual que protege o direito à autoria científica ou literária (direitos autorais), direito à liberdade pensamento e direito à liberdade de expressão.

Por outro lado, os direitos de personalidade são o conjunto de direitos que formam uma categoria especial que possui suas próprias características na ordem jurídica. As principais características dos direitos da personalidade são as seguintes: indisponibilidade (intransmissíveis e irrenunciáveis); absolutos; imprescritíveis; impenhoráveis; extrapatrimoniais; e vitalícios.

Dessa forma, os direitos de personalidade são os direitos subjetivos aplicados e regulados pelo direito privado, com a finalidade de proteger os atributos do ser humano (integridade física, moral e intelectual) e os valores da personalidade do indivíduo ${ }^{8}$, em face das ofensas e violações praticadas outros indivíduos nas relações particulares.

\subsection{A DIGNIDADE DA PESSOA HUMANA E SUA RELAÇÃO COM OS DIREITOS FUNDAMENTAIS E OS DIREITOS DA PERSONALIDADE (RELAÇÃO TRIDIMENSIONAL)}

A dignidade da pessoa humana é o princípio que fundamenta a estrutura a ordem jurídico-constitucional e do Estado Democrático de Direito, sendo diretriz de interpretação e de aplicação dos direitos fundamentais e dos direitos de personalidade para assegurar o respeito, proteção e promoção dos direitos do ser humano em todos os seus sentidos.

A pessoa humana é a gênese de valores éticos que gravitam sobre o ordenamento jurídico e constitui principal tarefa-finalidade do Estado, da sociedade e dos particulares para resguardar os valores intrínsecos das pessoas e de proteger os seus aspectos físicos, morais e intelectuais. Nos dizeres de Miguel Reale, a pessoa humana é o valor fonte da ordenação axiológica porque possui a faculdade de outorgar sentido aos atos e as coisas, bem como pela consciência de sua dignidade não só pelo mero fato de existir, mas pelo significado e o sentido de sua existência, que traduz: "como autoconsciência espiritual, é o valor que dá sentido a todo evolver histórico, ou seja, valor a cuja atualização tendem os renovados esforços do homem em sua faina civilizadora”. (REALE, 2002, p. 2010).

O conteúdo da dignidade humana reconhece a elevação do ser humano ao centro da ordem jurídico-positiva e confere sentido às normas que foram elaboradas para o ser humano e à sua relação existencial, a fim de proporcionar a garantia dos mínimos direitos condizentes 
com a dignidade da pessoa individualmente considerada (FARIAS; ROSENVALD, 2015, p.

127). Nesse contexto, a dignidade representa um princípio jurídico e valor fundamental com origem nos direitos humanos, que exerce dupla função de fornecer a compreensão nuclear dos direitos fundamentais para interpretação das normas ambíguas ou lacunosas e de resolver as colisões de direitos envolvendo aspectos morais (BARROSO, 2014, p. 111).

O iluminismo foi um movimento filosófico, caracterizado pela racionalidade e pelo reconhecimento do homem como origem e fundamento da ordenação social, que consolidou a noção dos direitos subjetivos oponíveis contra o Estado e os particulares, outorgando às pessoas mecanismos endógenos e operacionais para a tutela de poderes e faculdades inerentes à dignidade da pessoa humana e da autonomia da vontade (SOUZA, 2011, p. 91-92).

Como se observa, historicamente, não existia uma relação dos direitos subjetivos do ser humano (direitos fundamentais e direitos de personalidade) com a dignidade da pessoa humana, tendo em vista que foram consagrados em momentos diversos e possuíam interesses e finalidades distintas. No entanto, a vinculação jurídico-positiva entre direitos fundamentais e dignidade da pessoa humana teve início com a instituição do Estado Social de Direito, mais precisamente com o advento das Constituições e dos tratados internacionais posteriores à Segunda Guerra Mundial (MIRANDA, 2009, p. 168).

A incorporação da dignidade humana em Declarações internacionais de Direitos Humanos e na ordem jurídica do Estado, como princípio constitucional, viabilizou a construção e a formação da cláusula geral de proteção à pessoa e reaproximou os direitos fundamentais e os direitos da personalidade, com a finalidade de assegurar uma tutela civilconstitucional. Os direitos fundamentais e os direitos da personalidade estão conexos por força do princípio da dignidade da pessoa humana, através de uma relação tríade que forma um núcleo intangível ou uma unidade indissolúvel.

Nestes termos, Jorge Miranda afirma que a Constituição esta assentada na dignidade da pessoa humana, como fundamento da sociedade e do Estado, que confere unidade de sentido e de valoração para conjugação dos direitos fundamentais e dos direitos de personalidade para assegurar a proteção e o desenvolvimento da pessoa, conforme se verifica:

\footnotetext{
“A Constituição confere uma unidade de sentido, de valor e de concordância prática ao sistema de direitos fundamentais. E ela repousa na dignidade da pessoa humana, ou seja, na concepção que faz da pessoa fundamento e sim da sociedade do Estado. Pelo menos, de modo directo e evidente, os direitos, liberdades e garantias pessoais e os direitos económicos, sociais e culturais comuns têm a sua fonte ética na dignidade da pessoa, de todas as pessoas. Mas quase todos os
} 
outros direitos, ainda quando projectados em instituições, remontam à ideia de proteção e desenvolvimento das pessoas. A copiosa extensão do elenco não deve fazer perder de vista esse referencial. [...]. Para além da unidade do sistema, o que conta é a unidade da pessoa. A conjugação dos diferentes direitos e das normas constitucionais, legais e internacionais a eles atinentes torna-se mais clara a essa luz. O "homem situado" no mundo plural, conflitual e em acelerada mutação do nosso tempo encontra-se muitas vezes dividido por interesses, solidariedades e desafios discrepantes; só na consciência da sua dignidade pessoal retoma unidade de vida e de destino.” MIRANDA, 2009, 169).

Conforme ensina Anderson Schreiber, a ciência jurídica contemporânea visa superar o abismo tradicional criado pelos juristas entre direito público e o direito privado para reunificar as duas esferas em torno da unidade constitucional por meio do princípio da dignidade da pessoa humana, isso significa que os direitos de personalidade e os direitos fundamentais estão correlacionados como consectários da dignidade humana (SCHREIBER, 2011, p. 13).

Do mesmo modo Rabindranath Valentino Aleixo Capelo de Souza reconhece tendência da tutela dos direitos da personalidade pela norma constitucional como direitos fundamentais em face do reconhecimento constitucional da dignidade da pessoa humana, bem como em razão do reconhecimento da dimensão relacional entre os direitos fundamentais e os direitos de personalidade (SOUZA, 2011, p. 585). No mesmo sentido, Antonio Enrique Pérez Luño assevera que a dignidade da pessoa humana é o valor básico que fundamenta os direitos do ser humano que tendem explicar e atender as necessidades das pessoas e conferir legitimidade para criação dos direitos da pessoa (LUÑO, 2010, p. 324).

Por fim, Ingo Wolfgang Sarlet também entende que existe uma indissociável relação entre o princípio da dignidade da pessoa humana e os direitos fundamentais. A dignidade da pessoa humana é o fundamento e o conteúdo da enunciação dos direitos fundamentais, que assegura a proteção e promoção dos direitos do ser humano (SARLET, 2015a, p. 125).

Os direitos fundamentais e os direitos de personalidade se assemelham no seu aspecto material, uma vez que foram normatizados para proteger os indivíduos das violações perpetradas pelo Estado e pelos particulares. A dignidade da pessoa humana é um princípio de diretriz para interpretação e aplicação dos direitos fundamentais e dos direitos de personalidade, que objetiva resguardar a proteção da pessoa sob a ótica da tutela civilconstitucional.

A cláusula geral de proteção da pessoa está assentada na relação tridimensional que realiza a correlação entre o princípio da dignidade da pessoa humana com os direitos fundamentais e os direitos de personalidade. A relação dialógica e integradora entre princípio 
da dignidade da pessoa humana, os direitos fundamentais e os direitos de personalidade, viabiliza a formação da cláusula geral de proteção do ser humano.

Nestes termos, vale ressaltar que esta relação tríade formada pela dignidade da pessoa humana (art. $1^{\circ}$, inciso III, CF/88), os direitos fundamentais (art. $5^{\circ} \mathrm{CF} / 88$ ) e os direitos de personalidade (art. $11 \mathrm{CC}$ ao art. $21 \mathrm{CC}$ ) foi incorporada pela ordem jurídica brasileira como forma de concretização dos valores constitucionais da igualdade, liberdade e de justiça presentes no Estado Democrático de Direito.

A tutela civil-constitucional e a cláusula geral de proteção da pessoa são concretizadas no plano jurídico em virtude da relação tridimensional conjugada pela dignidade humana (valor) com os direitos fundamentais e de personalidade (norma), que visa unificar os diferentes regimes do Direito Público e do Direito Privado, para conferir a proteção da pessoa em todos os seus aspectos (físicos, morais e intelectuais) e de

responsabilizar o Estado e os particulares das ofensas e violações praticadas, através de ações judiciais de reparação dos danos.

A diferença formal entre os direitos fundamentais e direitos da personalidade devem estar interligados com o seu aspecto material, fundamentado no princípio da dignidade da pessoa humana. Na verdade, a relação entre o princípio da dignidade da pessoa humana, os direitos fundamentais e os direitos de personalidade visa à formação de uma unidade indivisível de proteção à pessoa em todos os aspectos (físico, moral e intelectual), o que justifica a construção da cláusula geral de proteção do ser humano e a sua tutela no plano civil-constitucional.

A consagração do princípio da dignidade da pessoa humana na Constituição sedimentou a construção da cláusula geral de proteção e a unificação dos direitos públicos e privados, ampliando os meios de proteção aos bens jurídicos inerentes à pessoa humana nas relações com o Estado e com outros indivíduos nas relações particulares. O processo de normatização da dignidade da pessoa humana fundamenta a enunciação e a correlação dos direitos fundamentais e dos direitos da personalidade.

A correlação entre os direitos fundamentais e os direitos de personalidade recebe o beneplácito dos Tribunais Superiores, que aplica o princípio da dignidade da pessoa humana para integrar lacunas normativas, para resolver colisões de direitos ou para servir de diretriz de interpretação na aplicação de direitos fundamentais e dos direitos de personalidade ${ }^{9}$. A justificativa da cláusula geral de proteção, por meio da conexão entre os direitos fundamentais 
e os direitos de personalidade, torna efetivada a tutela civil-constitucional à luz do princípio da dignidade da pessoa humana.

O Supremo Tribunal Federal (STF) e o Superior Tribunal de Justiça (STJ) utilizam o princípio da dignidade da pessoa humana para concretizar a clausula geral de proteção da pessoa e fazer a ligação com os direitos fundamentais e os direitos de personalidade, viabilizando a efetivação da garantia tutela civil-constitucional.

Oportuno destacar que no julgamento da ADPF $132^{10}$, o Tribunal reconheceu a união

homoafetiva como instituto jurídico, assegurando a possibilidade de casais do mesmo sexo constituírem uniões estáveis, com fundamento no princípio da dignidade da pessoa humana como promoção de direitos. Por sua vez, no julgamento do RE $248869^{11}$, o Tribunal fez referência do direito ao nome como corolário do princípio da dignidade da pessoa humana que traduz na identidade pessoal e na origem de sua ancestralidade.

Do mesmo modo, no HC $71.373^{12}$, o Tribunal entendeu que o investigado, na ação

de paternidade, não poderá ser submetido à força pelo Estado para realização de exame de

DNA, em respeito à intimidade, à manutenção da integridade física e moral e da intangibilidade do corpo humano, a fim de assegurar a preservação da dignidade humana.No julgamento da ADI $2649^{13}$, houve a declaração da constitucionalidade da Lei $n^{\circ}$ 8.899/94, com o objetivo de assegurar às pessoas com deficiência o seu acesso ao transporte público, concretizando o princípio da dignidade da pessoa humana.

No Recuso Especial 1169337/SP ${ }^{14}$, o princípio da dignidade da pessoa humana foi

utilizado como diretriz de interpretação para colisão entre direitos fundamentais e direitos de personalidade, sendo assegurado o respeito e a proteção à honra e a imagem da pessoa em face das ofensas perpetrada por particulares em jornais de informação. Em outro julgado, o Tribunal deferiu o pedido de homologação de sentença estrangeira que autorizou a modificação do nome do menor, através da extração do nome de família do pai biológico, em razão da mãe biológica ter contraído novas núpcias e preferir a utilização do sobrenome do novo consorte, de forma para tutelar os direitos de personalidade e respeitar a dignidade da pessoa humana. $^{15}$

No julgamento do REsp $617.588 / \mathrm{SP}^{16}$ e do Resp 684.442/RS ${ }^{17}$, o princípio da dignidade da pessoa humana foi aplicado para assegurar o fornecimento da prestação de serviços essenciais à vida humana (água e energia elétrica) em razão da inadimplência do pagamento das faturas, isto é, assegurou a proteção das condições mínimas para uma vida diga. 
No Tribunal Constitucional de Portugal, o princípio da dignidade da pessoa humana foi utilizado para efetivar os direitos fundamentais e os direitos de personalidade, assegurando o direito a um mínimo de existência condigna (mínimo existencial) inerente ao princípio do respeito da dignidade humana. ${ }^{18}$ Em outro julgado, declarou a inconstitucionalidade da lei que admitia a penhora de vencimentos em montante capaz de privar a pessoa de dispor de um rendimento mensal mínimo necessário à sua subsistência, o que desrespeita o princípio da dignidade da pessoa humana. ${ }^{19}$

As interlocuções entre os direitos fundamentais e os direitos da personalidade são integradas pelo princípio da dignidade da pessoa humana, através de uma sua relação tridimensional, que objetiva a efetivação da cláusula geral de proteção da pessoa no seu aspecto físico, moral e intelectual sob o enfoque da tutela civil-constitucional.

A assimetria entre os direitos fundamentais e os direitos de personalidade foi reconstruída com o princípio da dignidade da pessoa humana ao estabelecer uma interpretação unificadora. A proteção da pessoa e a sua tutela civil-constitucional emergem de uma relação

tríade formada pelo princípio da dignidade da pessoa humana que é o sustentáculo e diretriz para interpretação e aplicação dos direitos fundamentais e dos direitos de personalidade.

Nos conflitos normativos envolvendo os direitos fundamentais e os direitos da personalidade, sugere-se à aplicação do princípio da dignidade da pessoa humana para solução da antinomia das normas e para assegurar a efetiva tutela dos direitos das pessoas noa esfera civil-constitucional, conforme os critérios da proporcionalidade e da preponderância dos interesses.

Dessa forma, a cláusula geral de proteção é construída pela normatividade da dignidade da pessoa humana, que perfaz a correlação dos direitos fundamentais e dos direitos da personalidade por meio de uma relação tridimensional, com a finalidade de assegurar a tutela civil-constitucional dos atributos das pessoas e dos direitos subjetivos.

\section{CONCLUSÃO}

A personalidade jurídica da pessoa se inicia a partir do nascimento com vida, sendo ressalvada desde a concepção, momento que passa a titularizar direitos e contrair obrigações na ordem civil. O Direito visa regular as relações dos indivíduos e resguardar a proteção dos 
atributos das pessoas em seus aspectos físicos, morais e intelectuais, como vida, liberdade, integridade física e psíquica, imagem, honra, liberdade de pensamento, privacidade, intimidade, identidade, dentre outros.

A Segunda Guerra Mundial foi responsável pela modificação da estrutura jurídicopositiva que motivou a consagração da inviolabilidade da dignidade da pessoa humana e dos direitos fundamentais nas Constituições do Estado, com a finalidade de proteger os direitos subjetivos dos indivíduos das violações perpetradas pelas autoridades públicas. Posteriormente, os direitos subjetivos das pessoas também foram protegidos contra as agressões praticadas pelos particulares nas relações privadas, consolidando a construção dos direitos de personalidade.

Todavia, com o advento da globalização e dos avanços tecnológicos, os sistemas de proteção dos direitos da pessoa se tornaram mais complexos e insuficientes em virtude do aumento de violações aos direitos fundamentais e de personalidade, o que demandou a superação da dicotomia entre os regimes de direito público e do direito privado para construção da cláusula geral de proteção de direitos e da dignidade da pessoa humana.

Conforme se verifica, o fenômeno da constitucionalização reformulou os meios de interpretação jurídica para compatibilizar as normas dos diversos ramos do Direito à luz da

Constituição Federal. Assim sendo, o princípio da dignidade da pessoa humana repersonalizou a ordem jurídica para unificar a proteção dos direitos subjetivos - direitos fundamentais e direitos de personalidade - por meio da cláusula geral de proteção para assegurar uma tutela civil-constitucional.

O princípio da dignidade da pessoa humana fundamenta a enunciação e a ligação das categorias dos direitos fundamentais e dos direitos de personalidade para formação da cláusula geral de proteção da pessoa, centralizando o indivíduo como prioridade do Estado e de toda coletividade. Nesse sentido, a dignidade da pessoa humana, os direitos fundamentais e os direitos de personalidade formaram o núcleo intangível ou unidade normativa de direitos dos seres humanos.

A cláusula geral de proteção da pessoa tem a função de norma integradora para solução de controvérsias sem previsão legal ou para preenchimento de lacunas normativas; norma interpretativa que visa orientar o jurista na busca do sentido jurídico e de solucionar conflitos normativos; norma diretiva que determina diretriz e estabelece objetivos para promoção e proteção dos direitos fundamentais e dos direitos de personalidade; norma 
unificadora que confere unidade normativa na conjugação dos direitos fundamentais e dos direitos de personalidade para concretizar a tutela civil-constitucional.

Por tais razões, a relação tridimensional deriva do princípio da dignidade da pessoa humana, dos direitos fundamentais e dos direitos de personalidade, em que se assenta a cláusula geral de proteção do indivíduo e dos direitos subjetivos. O Estado e os particulares estão vinculados à clausula geral de proteção, para garantir a tutela civil-constitucional nas dimensões físicas, morais e intelectuais da pessoa humana, mediante a disponibilização de mecanismos jurídicos eficazes para fazer cessar as ameaças e responsabilizar os ofensores pelos danos causados à vítima.

A cláusula geral de proteção assegura à pessoa, na condição de sujeito titular de direitos e obrigações, a inviolabilidade da dignidade humana e de sua personalidade na ordem jurídica. Por seu turno, os direitos fundamentais e os direitos de personalidade são garantidos pelo Estado como forma de defesa e de promoção do ser humano em todos os seus aspectos.

Em síntese, a formação da unidade da cláusula geral de proteção realiza a interligação do princípio da dignidade da pessoa humana com os direitos fundamentais e os direitos de personalidade para proteger a pessoa em todas as suas dimensões (físicas, psíquicas, morais e intelectuais), contra as agressões do Estado ou dos particulares, através de instrumentos jurídicos preventivos e reparadores das lesões, tornando eficaz a tutela civilconstitucional dos direitos subjetivos.

\section{REFERÊNCIAS BIBLIOGRÁFICAS}

AMARAL, Francisco. Direito Civil: introdução. $8^{\mathrm{a}}$ ed. Rio de Janeiro: Renovar, 2014. ARAÚJO, Luiz Alberto David. Diferenças Individuais e Concurso Público: reflexões iniciais

sobre os critérios de seleção do estado para as carreiras jurídicas. In: NETO, Francisco José Rodrigues de Oliveira et. al (Org). Constituição e Estado Social: os obstáculos à concretização da constituição. São Paulo: Revista dos Tribunais; Coimbra: Coimbra Editora, 2008.

São

; NUNES JÚNIOR, Vidal Serrano. Curso de Direito Constitucional. $11^{\mathrm{a}} \mathrm{ed}$.

Paulo: Saraiva,

2007.

BARROSO, Luís Roberto. A dignidade da pessoa humana no direito constitucional contemporâneo: a construção de um conceito jurídico à luz da jurisprudência mundial. $3^{\mathrm{a}}$ reimp. Belo Horizonte: Fórum, 2014. 
. Neoconstitucionalismo e constitucionalização do direito: o triunfo tardio do direito constitucional no Brasil. 2015.Disponível em: $<\mathrm{http}: / /$ www.luisrobertobarroso.com.br/wpcontent/themes/LRB/pdf/neoconstitucionalismo -e

_constitucionalizacao_do_direito_pt.pdf $>$. Acesso em: 29 de julho de 2015, às

17h:55min. BITTAR, Carlos Alberto. Os direitos da personalidade. $8^{\mathrm{a}}$ ed. São Paulo:

Saraiva, 2015. BONAVIDES, Paulo. Curso de Direito Constitucional. 29a ed. São Paulo:

Malheiros, 2014.

BRASIL, Constituição da República Federativa do Brasil de 1988, de 5 de outubro de 1988. Disponível em: <http:/www.planalto.gov.br/ccivil_03/constituicao/constituicao.htm>. Acesso em: 15 de agosto de 2015, às 13h:28min.

BRASIL, Lei $\mathrm{n}^{\mathrm{o}}$ 10.406, de 10 de janeiro de 2002. Institui o Código Civil. Disponível em:

<http://www.planalto.gov.br/ccivil_03/leis/2002/L10406.htm>. Acesso em: 15 de agosto de

2015, às

13h:27min.

BRASIL, Superior Tribunal de Justiça. Recurso Especial 1008398/SP. Relatora Ministra Nancy Adrighi, Brasilia, julgado no dia 15 de outubro de 2009, pulicado no dia 18 de novembro de $2009 . \quad$ Disponível em: $<$ https://ww2.stj.jus.br/websecstj/cgi/revista/REJ.cgi/ITA?seq=920837\&tipo=0 \&nreg=200 70

2733605\&SeqCgrmaSessao=\&CodOrgaoJgdr=\&dt=20091118\&formato=PDF\&salvar=fals e>

- Acesso em: 29 de julho de 2015, às 20h:13min.

BRASIL, Superior Tribunal de Justiça. Recurso Especial 1169337/SP. Relator Min. Luis Felipe Salomão, julgado no dia 18 de novembro de 2014, publicado em 18 de dezembro de

$2014 . \quad$ Disponível em:

$<$ https://ww2.stj.jus.br/processo/revista/documento/mediado/?componente=ITA\&sequencia l=

$1365933 \&$ num_registro $=200902371635 \&$ data $=20141218 \&$ formato $=P D F>$. Acesso em: 29 de julho de 2015, às 20h:53min.

BRASIL, Superior Tribunal de Justiça. Recurso Especial 617588/SP. Relator: Min. Luiz Fux, Brasilia, julgado no dia 27 de abril de 2004, publicado em 31 de maio de 2004.Disponível em:

$<$ https://ww2.stj.jus.br/processo/revista/documento/mediado/?componente=ITA\&sequencia $1=$

$470693 \&$ num_registro $=200302353999 \&$ data $=20040531 \&$ formato=PDF $>$. Acesso em: 10 de agosto de 2015, às 10h:08min. 
BRASIL, Superior Tribunal de Justiça. Recurso Especial 684.442/RS. Relator: Min. José

Delgado, Brasilia, julgado no dia 03 de fevereiro de 2005, publicado em 05 de setembro de

2005.Disponível

em:

$<\mathrm{https} / /$ ww2.stj.jus.br/processo/revista/documento/mediado/?componente=ITA\&sequencia $1=$

524116\&num_registro $=200401209590 \&$ data $=20050905 \&$ formato=PDF $>$. Acesso em: 10 de agosto de 2015, às 10h:06min.

BRASIL, Superior Tribunal de Justiça. Sentença Estrangeira Contestada 5.726/EX. Relatora Ministra. Maria Thereza de Assis Moura, Brasilia, julgado no dia 29 de agosto de 2012, publicado em 13 de setembro de 2012. Disponível em: <https://ww2.stj.jus.br/processo/revista/documento/mediado/?componente=ITA\&sequencia $1=$

$1174455 \&$ num_registro $=201200554470 \&$ data $=20120913 \&$ formato $=P D F>$. Acesso em: 29 de julho de 2015, às 21h:02min.

BRASIL, Supremo Tribunal Federal (STF). Ação Direta de Inconstitucionalidade 2649. Relatora Min. Cármen Lúcia, Brasilia, julgado no dia 08 de maio de 2008, publicado em 17 de outubro de 2008.2 Disponível em: $<$ http://redir.stf.jus.br/paginadorpub/paginador.jsp?docTP=AC\&docID=555517>. Acesso em:

29 de julho de 2015, às

20h:13min.

BRASIL, Supremo Tribunal Federal. Arguição de Descumprimento de Preceito Fundamental

132. Relator Min. Ayres Britto, Brasilia, julgado no dia 05 de março de 2011, publicado em

14 de outubro de 2011. Disponível em: $<$ http://redir.stf.jus.br/paginadorpub/paginador.jsp?docTP=AC\&docID=628633>. Acesso em:

29 de julho de 2015, às

20h:14min.

BRASIL, Supremo Tribunal Federal. Recurso Extraordinário 248869/SP. Relator Min. Maurício Corrêa, Brasília, julgado no dia 07 de agostos de 2003, publicado em 12 de março de $2004 . \quad$ Disponível em: $<$ http://redir.stf.jus.br/paginadorpub/paginador.jsp?docTP=AC\&docID=257829>. $\quad$ Acesso em:

29 de julho de 2015, às

20h:13min.

BRASIL. Supremo Tribunal Federal. Habeas Corpus 71.373/RS. Relator: Min. Francisco Rezek, Brasília, julgado no dia 10 de novembro de 1994, publicado em 22 de novembro de

1996.

Disponível

em:

<http://redir.stf.jus.br/paginadorpub/paginador.jsp?docTP=AC\&docID=73066>.

Acesso em: 
29 de julho de 2015, às

20h:13min.

CONSTITUIÇÃO DA REPÚBLICA FEDERAL DA ALEMANHA (LEI FUNDAMENTAL DE BONN). 2015. Disponível em: <https://www.btg-bestellservice.de/pdf/80208000.pdf>. Acesso em: 29 de julho de 2015, às 18h:00min.

COSTA NETO, João. Dignidade humana: visão do Tribunal Constitucional Alemão, do STF

$e$ do Tribunal Europeu. São Paulo: Saraiva, 2014.

DIMOULIS; Dimitri; MARTINS, Leonardo. Teoria Geral dos Direitos Fundamentais. $5^{\mathrm{a}}$ ed. São Paulo: Atlas, 2014.

FARIAS, Cristiano Chaves de; ROSENVALD, Nelson. Curso de Direito Civil: parte geral $e$

LINDB. 13ª ed. São Paulo: Atlas, 2015.

GOMES, Orlando. Introdução ao Direito Civil. 12a ed. Rio de Janeiro: Forense, 1996.

HESSE, Konrad. Temas Fundamentais do direito constitucional. São Paulo: Saraiva, 2009.

KANT, Immanuel. Fundamentação da metafísica dos costumes e outros escritos. $2^{\mathrm{a}}$

reimp.

São Paulo: Martin Claret, 2011.

LUÑO, Antonio Enrique Pérez. Derechos Humanos, Estado de Derecho y Constitución. $10^{\mathrm{a}}$

ed. Madrid: Editorial Tecnos, 2010.

MENDES, Gilmar Ferreira; BRANCO, Paulo Gustavo Gonet. Curso de Direito

Constitucional. 9a ed. São Paulo: Saraiva, 2014.

MIRANDA, Jorge. Manual de Direito Constitucional. Tomo IV: direitos fundamentais. $5^{\mathrm{a}}$ ed. Coimbra: Coimbra Editora, 2014.

- A dignidade da pessoa humana e a unidade valorativa do sistema de direitos fundamentais. In: MIRANDA, Jorge; SILVA, Marco Antonio Marques da (coord.). Tratado Luso-Brasileiro da Dignidade Humana. 2a ed. São Paulo: QuartierLatin, 2009.

PÉREZ, Jesús González. La dignidade de la persona. 2 2 ed. Madrid: Civitas, 2011. PORTUGAL. Tribunal Constitucional. Acórdão no 509/02. Rel. Cons. Luís Nunes de

Almeida, Lisboa, julgado no dia 19 de dezembro de 2002. Disponível em: 
$<$ http://www.tribunalconstitucional.pt/tc/acordaos/20020509.html $>$. Acesso em: 10 de agosto de 2015, às $14 \mathrm{~h}: 58 \mathrm{~min}$.

PORTUGAL. Tribunal Constitucional. Acórdão no 96/04. Rel. Cons. Maria Helena Brito, Lisboa, julgado no dia 11 de fevereiro de 2004. Disponível em:<http//www.tribunalconstitucional.pt/tc/acordaos/20040096.html $>$. Acesso em: 10 deagosto de 2015, às 15h:43min.

REALE, Miguel. Filosofia do Direito. $20^{\mathrm{a}}$ ed. São Paulo: Saraiva, 2002.

ROCHA, Cármen Lúcia Antunes. O princípio da dignidade da pessoa humana e a exclusão social. Interesse Público, São Paulo, ano 1, nº 4, out./nov. 1998.

SARLET, Ingo Wolfgang. A eficácia dos direitos fundamentais: uma teoria geral dos direitos fundamentais na perspectiva constitucional. $12^{\mathrm{a}}$ ed. Porto Alegre: Livraria do Advogado Editora, 2015.

. Dignidade (da pessoa) Humana e Direito Fundamentais na Constituição Federal de

1988. $10^{\mathrm{a}}$ ed. Porto Alegre: Livraria do Advogado Editora, 2015.

SCHREIBER, Anderson. Direitos da personalidade. São Paulo: Atlas, 2011. SILVA, De Plácido e. Vocabulário Jurídico. 31 a ed. Rio de Janeiro: Forense, 2014.

SILVA, José Afonso. A dignidade da pessoa humana como valor supremo da democracia. Revista de Direito Administrativo (RDA), Rio de Janeiro: Revista de Direito Administrativo (RDA), v. 212, abr/jun. 1998.

SOUZA, Rabindranath Valentino Aleixo Capelo de. $O$ direito geral de personalidade. Coimbra: Coimbra Editora, 2011.

SZANIAWSKI, Elimar. Direitos de personalidade e sua tutela. $2^{\mathrm{a}}$ ed. São Paulo: Revista dos

Tribunais,

2005.

TEPEDINO, Gustavo. A Tutela da Personalidade no Ordenamento Civil-constitucional Brasileiro. In: Temas de Direito Civil. $3^{\text {a }}$ ed. Rio de Janeiro: Renovar, 2004.

. Premissas Metodológicas para Constitucionalização do Direito Civil. In: Temas

de

Direito Civil. $3^{\text {a }}$ ed. Rio de Janeiro: Renovar, 2004.

\footnotetext{
${ }^{1} \mathrm{O}$ imperativo categórico representa que a pessoa, na condição de serhumano, deve ser tratada comdignidade por outros indivíduos. O ser humano é dotado de racionalidade com autonomia ética para agir conforme sua vontade, razão pela qual o homem é um fim em si mesmo, não admitindo que seja tratado como objeto de instrumentalização para outra finalidade diversa. Assim, se verifica: "Agora afirmo, o homem - e, de uma maneira gera, todo o ser racional - existe como um fim em si mesmo, e não apenas como meio para o uso arbitrário desta ou daquela vontade. Em todas as suas ações, pelo contrário, tanto nas direcionadas a
} 
ele mesmo como nas que o são os outros seres racionais, deve ser ele sempre considerado simultaneamente como fim." (KANT, 2011, p. 58).

${ }^{2}$ A respeito do ajustamento do princípio da dignidade à realidade social, mes mo na ausência de norma especial prevista para o caso concreto, verificar o precedente do Superior Tribunal de Justiça (STJ), cuja parte da redação merece destaque: "A falta de fôlego do Direito em acompanhar o fato social exige, pois, a invocação dos princípios que funcionam como fontes de oxigenação do ordenamento jurídico, marcadamente a dign idade da pessoa humana - cláusula geral que permite a tutela integral e unitária da pessoa, na solução das questões de interesse existencial humano.” (BRASIL, Superior Tribunal de Justiça. Recurso Especial 1008398/SP. Relatora Ministra Nancy Adrighi, Brasília, julgado no dia 15 de outubro de 2009, pulicado no dia 18 de novembro de

200

9).

${ }^{3}$ A função integradora e interpretativa da dignidade da pes soa humana diz respeito à sua conexão comos direitos fundamentais, em que enfatiza a utilização do princípio da dignidade humana como critério para construção de um conceito materialmente aberto e receptivo dos direitos fundamentais previstos na Constituição (SARLET,

2015 ,

p.112).

${ }^{4}$ A diferença dos direitos fundamentais e dos direitos de personalidade na ordem jurídica brasileira é realizada da seguinte forma: I) Aplicação normativa: os direitos fundamentais são aplicados no contexto das relações públicas, estabelecidas entre indivíduo e Estado, uma vezque se originaramdos ideais liberais contra os abusos e arbitrariedades praticadas pelo soberano (eficácia vertical). Os direitos da personalidade são aplicados nas relações privadas entre os particulares, sendo que surgiramcom a evolução social e tecnológica com a finalidade de assegurar a proteção dos atributos do indivíduo em face dos abusos perpetrado pelos particulares (eficácia horizontal); II) Competência legislativa: a competência legislativa para criar e incluir novos direitos fundamentais é do Poder Constituinte (originário ou derivado). A competência para disciplinar sobre direitos da personalidade é privativa da União (art. 22, inciso I, CF/88); III) Regime jurídico: os direitos e garantias fundamentais pertencem ao regime do direito público ou Direito Constitucional (art. $5^{\circ} \mathrm{CF} / 88$ ). Os direitos da personalidade estão vinculados ao direito privado ou Direito Civil (art. 11 e art. 21 CC); IV) Sistema de

garantias: os direitos fundamentais são assegurados por meio das garantias das ações constitucionais (direito de petição, ação popular, ação civil pública, mandado de segurança, habeas data, habeas corpus) e ações de controle de constitucionalidade. Os direitos de personalidade são assegurados de forma preventiva por meio de ação inibitória (art. 12 CC e art. 273 CPC c/c art. 461 CPC) ou de forma reparadora por meio da responsabilidade civil de indenização (art. $12 \mathrm{CC}$ e art. $927 \mathrm{CC}$ ).

5 “A defesa de que certo número de direitos preexistem ao próprio Estado, por resultarem da natureza humana, desvenda características crucial do Estado, que lhe empresta legitimação - o Estado serve aos cidadãos, é instituição concatenada para lhes garantir os direitos básicos. Essas ideias tiveram decisiva influência sobre a Declaração de Direitos de Virgínea, de 1776, e sobre a Declaração Francesa, de 1789. Talvez, por isso, com maior frequência, situa-se o ponto fucral do desenvolvimento dos direitos fundamentais na segunda metade do século XVIII, sobretudo com o Bill of Rights de Virgínia (1776), quando se dá a positivação dos direitos tidos como inerentes ao homem, até ali mais afeiçoados a reivindicações políticas e filosóficas do que a normas jurídicas obrigatórias, exigíveis judicialmente.” (MENDES; BRANCO, 2014, p 16).

6

Artigo

1

(1) a dignidade da pessoa humana é intangível. Respeitá-la e protege-la é obrigação de todo o poder público. Artigo 2

(1) Todos têm o direito ao livre desenvolvimento da sua personalidade, desde que não violem os direitos de outros e não atentem contra a ordemconstitucional.

${ }^{7}$ Segundo a definição de Francisco Amaral: "Direitos da personalidade são direitos subjetivos ou melhor, situações jurídicas existenciais que têm por objetivo os bens e valores essenciais da pessoa, de natureza física, moral e intelectual. Como direito ou situações jurídicas subjetivas, conferem ao seu titular o poder de agir na defesa dos bens ou valores essenciais da personalidade, que compreendem no seu aspecto físico, o direito à 
vidae ao próprio corpo; no aspecto intelectual, o direito à liberdade de pensamento, direito de autor e inventor; e no aspecto moral, o direito à liberdade, à honra, ao recato, ao segredo, à imagem, à identidade, e, ainda, o direito de exigir de terceiros o respeito a esses direitos." (AMARAL, 2014, p. 301-302).

${ }^{8}$ Conforme ensina Gustavo Tepedino, os direitos de personalidade são direitos subjetivos que tutelamos valores da pessoa humana nas relações de direito privado: "Na medida em que a pessoa humana torna-se objeto de tutela também nas relações de direito privado, com o estabelecimento de direitos subjetivos para a tutela de valores atinentes à personalidade, tratam os civilistas de definir sua configuração dogmática, delineando-se um direito iluminado pelo paradigma dos direitos subjetivo privado por excelência, o direito de propriedade. Cogita-se, nesta esteira, que tais direitos pertencem à categoria dos direitos privados exatamente porque a vida, a integridade física, a honra, a liberdade, satisfazem aspirações e necessidades próprias do indivíduo em si mesmo considerado, e inserem-se, portanto, na esfera da utilitas privada". (TEPEDINO, 2004. p. 32).

${ }^{9}$ No Direito Constitucional brasileiro a incidência do princípio da dignidade da pessoa humana abrange os seguintes aspectos: a) ambiguidade de linguagem em que o parâmetro de escolha de uma solução e não de outra deverá estar pautada na que tiver melhor consonância com a dignidade humana; b) lacuna normativa, na qual a dignidade humana será utilizada para fazer a integração normativa; c) colisões de normas constitucionais e direitos fundamentais, a dignidade humana é utilizada como critério de solução de colisões de direitos; d) desacordo moral razoável, sendo que a dignidade humana é invocada como reforço argumentativo ou elemento de argumentação (BARROSO, 2014, p. 114).

${ }^{10}$ BRASIL, Supremo Tribunal Federal. Arguição de Descumprimento de Preceito Fundamental 132. Relator Min. Ayres Britto, Brasília, julgado no dia 05 de março de 2011, publicado em 14 de outubro de 2011.

${ }^{11}$ BRASIL, Supremo Tribunal Federal. Recurso Extraordinário 248869. Relator Min. Maurício Corrêa, Brasília, julgado no dia 07 de agostos de 2003, publicado em 12 de março de 2004.

${ }^{12}$ BRA SIL. Supremo Tribunal Federal. Habeas Corpus 71.373. Relator: Min. Francisco Rezek, Brasília, julgado no dia 10 de novembro de 1994, publicado em 22 de novembro de 1996.

${ }^{13}$ BRASIL, Supremo Tribunal Federal (STF). Ação Direta de Inconstitucionalidade 2649. Relatora Min. Cármen

Lúcia, Brasília, julgado no dia 08 de maio de 2008, publicado em 17 de outubro de

2008.

${ }^{14}$ BRASIL, Superior Tribunal de Justiça (STJ). Recurso Especial 1169337/SP. Relator Min. Lui s Felipe

Salomão, julgado no dia 18 de novembro de 2014, publicado em 18 de dezembro de 2014.

${ }^{15}$ BRASIL, Superior Tribunal de Justiça. Sentença Estrangeira Contestada 5.726/EX. Relatora Ministra. Maria

Thereza de Assis Moura, Brasília, julgado no dia 29 de agosto de 2012, publicado em 13 de setembro de 2012.

${ }^{16}$ BRASIL. Superior Tribunal de Justiça. Recurso Especial 617.588/SP. Relator: Min. Luiz Fux, Brasília, julgado no dia 27 de abril de 2004, publicado em 31 de maio de 2004.

${ }^{17}$ BRASIL. Superior Tribunal de Justiça. Recurso Especial 684.442/RS. Relator: Min. José Delgado, Brasília, julgado no dia 03 de fevereiro de 2005, publicado em 05 de setembro de 2005.

${ }^{18}$ PORTUGAL. Tribunal Constitucional. Acórdão nº 509/02. Rel. Cons. Luís Nunes de Almeida, Lisboa, julg ado no dia 19 de dezembro de 2002.

${ }^{19}$ PORTUGAL. Tribunal Constitucional. Acórdão no 96/04. Rel. Cons. Maria Helena Brito, Lisboa, julgado no dia 11 de fevereiro de 2004. 